\title{
Students' Attitudes towards the Use of Slovene as L1 in Teaching and Learning of Business English at Tertiary Level
}

\author{
ABSTRACT
}

Over the past decades, the monolingual (English-only) approach to English language teaching and learning has prevailed. In recent years, however, the trend of using students' first language (L1) in teaching and learning English as a foreign language has re-emerged. However, the research on the use of L1 in teaching English for specific purposes is far from extensive. The aim of this study was to investigate the use of Slovene as the students' L1 in teaching and learning Business English at tertiary level. The specific objectives were to determine the students' attitudes towards the teachers' and the students' use of Slovene during Business English lessons and the students' use of Slovene in learning Business English. The present study was quantitative, with data gathered via a questionnaire. The results show that, on the one hand, there is some inclination towards the use of L1 both in class and during their study of Business English. On the other hand, the preference towards the use of predominantly (or exclusively) English in class is also present and is positively correlated with the level of students' knowledge of English. The results are of value to English language teachers as they suggest the contexts in which students' L1 could be used in the process of teaching and learning English for specific purposes.

Keywords: mother tongue/L1; Business English instruction; language functions; non-language functions; language learning efficiency

\section{Odnos študentov do uporabe maternega jezika pri poučevanju in učenju poslovne angleščine $v$ terciarnem izobraževanju}

\section{POVZETEK}

$\mathrm{V}$ zadnjih desetletjih je prevladoval enojezični pristop $\mathrm{k}$ poučevanju in učenju angleščine kot tujega jezika. Kljub temu pa se vse več študij ukvarja s proučevanjem vključevanja maternega jezika učencev v pouk angleščine kot tujega jezika. Vendar pa raziskave o uporabi maternega jezika pri poučevanju angleščine kot tujega strokovnega jezika niso zelo pogoste. Namen te študije je raziskati rabo slovenščine kot maternega jezika študentov pri poučevanju in učenju poslovne angleščine na terciarni stopnji s ciljem ugotoviti odnos študentov do učiteljeve rabe slovenščine in do njihove lastne rabe slovenščine med predavanji iz poslovne angleščine in pri njihovem učenju. $\mathrm{V}$ ta namen je bila izvedena kvantitativna raziskava, pri kateri smo z vprašalnikom pridobili mnenje študentov ekonomskih in poslovnih ved. Rezultati so pokazali, da nekateri študenti težijo $\mathrm{k}$ rabi slovenščine tako med predavanji kot tudi pri učenju poslovne angleščine, drugim pa je bližje enojezični pristop k usvajanju poslovne angleščine. To so predvsem študenti, ki imajo dobro ali odlično znanje poslovne angleščine. Rezultati so lahko koristni za poučevanje angleščine kot tujega jezika, saj kažejo na različne faktorje, ki vplivajo na usvajanje tujega jezika.

Ključne besede: materni jezik; poučevanje poslovne angleščine; jezikovne funkcije; nejezikovne funkcije; učinkovitost učenja tujega jezika 


\section{Students' Attitudes towards the Use of Slovene as L1 in Teaching and Learning of Business English at Tertiary Level}

\section{Introduction}

There is an ongoing debate in the field of teaching and learning English as a foreign language (EFL) about the inclusion or exclusion of the students' first language (L1) in this process. On the one hand, there is a school of thought that advocates the use of English only and the complete exclusion of students' L1 in class, i.e., both the teacher and the students should not resort to their L1 in the context of foreign language instruction and acquisition, with Krashen (1981) being the main supporter of this approach. On the other hand, there are those who support the inclusion of students' L1 in EFL teaching and learning (Deller and Rinvolucri 2002; Tang 2002; Nation 2003; Widdowson 2003; Brooks-Lewis 2009) because they see the use of L1 as beneficial for a number of reasons (as a means of lessening the anxiety of students with a lower level of foreign language proficiency regarding their use of the foreign language, building students' selfconfidence, giving L1 equivalents of foreign language terms, etc.).

Teaching English for specific purposes (ESP) shares a number of common features with teaching English for general purposes (EGP), as we can argue that both ESP and EGP are part of the English language and, consequently, one can adopt a similar (if not the same) method for teaching (and learning) either ESP or EGP. However, the main differences between these two 'areas' of English are shown in the context of teaching and in the purpose of instruction. That is, teaching and learning of ESP is carried out in order to obtain the knowledge of a specific segment of the English language which will be used in specific professional and/or vocational contexts. Students taking ESP courses learn English in order to be able to perform specific communicative tasks in English in their field of specialization. One of the main differences between ESP and EGP is seen in the use of specialized terminology pertinent to a given professional domain. Putting these differences between ESP and EGP aside, we can state that language teaching methods which are used in the context of EGP can also be applied in ESP teaching and learning contexts, as noted above.

In recent decades, a growing body of literature which recognises the importance of the use of students' L1 in this process has emerged (see, for example, Burden 2000; Tang 2002; Nation 2003; Dujmović 2007; Bouangeune 2009; Brooks-Lewis 2009; Cianflone 2009; Kovačić and Kirinić 2011; Debreli and Oyman 2015). Most frequently, these studies focus on teaching and learning English for general purposes. Nevertheless, this topic has also been investigated within the teaching and learning of English for specific purposes (see, for example, Fakharzadeh 2009; Kavaliauskienė 2009; Taylor 2014; Carrió-Pastor and Vallés 2015; Xhemaili 2016).

Studies on the use of students' L1 in foreign language teaching and learning have been performed also by Slovene researchers. These studies address the use of Slovene at different stages of language learning, from primary to tertiary education, and in different contexts (see, for example, Skela 1994, 2010; Grosman 2001, 2009; Pižorn 2008; Sešek 2009; Holc 2010; Stare Pušavec 2013). The use of Slovene as L1 in the teaching of foreign languages for specific purposes, however, has not been widely studied (Plos and Puklavec 2015).

The aim of this paper is to add to the body of knowledge on the use of Slovene as L1 in the process of teaching and learning English for specific purposes by reporting on our study, which aimed to 
establish students' attitudes towards the use of Slovene as their first language (L1) in teaching and learning Business English at tertiary level. To achieve this goal, a quantitative study was performed which focused on the attitudes of students taking Business English courses at tertiary level within their economics and business and business administration undergraduate studies.

The remaining part of the paper proceeds as follows. Section 2 gives a theoretical framework for the study. In Section 3, a presentation of the study design is given and in Section 4 the results of our study are presented and discussed. Finally, Section 5 summarizes the main findings with the implications of the findings for ESP teaching and for future research into the topic concerned.

\section{Theoretical Framework}

A huge variety of English (or any other foreign language) teaching methods have been advocated both past and present. As regards the use of L1 in teaching a foreign language (L2), we find methods that either welcome the inclusion of L1 or support the view that L1 should not be present in foreign language classes at all.

Historically, the grammar-translation method was largely dominant in foreign language teaching (Cook 2001a). As its name suggests, this method focuses on grammatical rules and structures as the basis for the instruction of L2 with the translation of different texts from one language to another. Although it supports the use of students' L1 (as a reference system for learning L2), it is not a method which would encourage the acquisition of communicative language skills because "most of the interaction in the classroom is from the teacher to the students [and there is] little student initiation and little student-student interaction" (Larsen-Freeman 2000, 16). Further, this method focuses mainly on reading and writing and little attention is given to listening and speaking (Larsen-Freeman 2000).

In contrast to this method, which utilized L1 in English language instruction, a number of well-established methods advocating 'English only' classes were developed in the past. These methods are, among others, the direct method and the audio-lingual method (Cook 2001a). The main principle behind the direct method is that in order to be able to communicate in L2, the students must learn how to think in that language. This method emphasises speaking over reading and vocabulary over grammar. "The initiation of the interaction goes both ways, from teacher to students and from student to teacher, although the latter is often teacher directed. Students converse with one another as well" (Larsen-Freeman 2000, 29). The audio-lingual method focuses on functional use of L2. Although it focuses on language structures (learning of vocabulary is not in the centre of attention) and although student-student interaction in L2 is common with this method, L2 is actually taught via drills (Larsen-Freeman 2000, 46-47).

Recently, emphasis has been given to the communicative approach, which focuses on the acquisition of communicative competence as the goal of learning a foreign language. It encourages the use of L2 "during communicative activities [and] for explaining the activities to the students or in assigning homework" (Larsen-Freeman 2000, 132). Carreres (2006) states that the communicative approach excludes the students' L1 from the EFL classroom, as it is considered as "counter-productive in the process of acquiring a new language, holding students back from expressing themselves freely in L2 and thus doing more harm than good" (as cited in Topolska-Pado 2011, 11).

The more recent approaches to foreign language learning are the task-based approach (Nunan 2004) and the content-based approach (Larsen-Freeman 2000). The main characteristic of the 
first approach is its aim of creating a learning environment for students which would enable them to use L2 as naturally as possible in their communication to complete a given task (LarsenFreeman 2000, 144). Concerning this approach, L1 use for the completion of tasks can be either an advantage or a disadvantage (i.e., the students may rely on the use of their L1 too much, which would reduce their use of L2). Regarding the content-based approach, which combines learning the language and some other specialized content, as is typical of ESP courses, (Larsen-Freeman 2000, 137), we see the benefit of L1 use mainly in the context of specialized terminology explanation (i.e., providing L1 equivalents of L2 terms).

As we have seen, opposing views and methods concerning the use of students' L1 in EFL teaching exist both in theory and in practice and all of these methods have benefits and drawbacks for the students' acquisition of English as a foreign language. Focusing on the 'English only' stance, the advocates of this approach argue that students should be immersed into English (as their L2), i.e., they should be exposed to as much English language input as possible, as this increases their acquisition of English (Cook 2001a). According to this belief, the thought processes associated with L1 and L2 should be kept apart, which means that in order to learn 'how to think' in English (and, consequently use English efficiently), students should not be exposed to their first language during EFL instruction (Cook 2001a).

However, the opponents of the 'English only' approach argue that the use of students' L1 in class is beneficial for a number of reasons. For example, students can benefit from L1 inclusion because they may feel safer in the English classroom, their progress can be faster at the beginner level, they may understand grammar better by comparing English (as L2) and L1 grammatical structures, and vocabulary similarities and differences may be presented (and learned) more easily; the students can basically draw on their knowledge of their L1 to facilitate their learning of English (Deller and Rinvolucri 2002, 10). From the teacher's perspective, by juxtaposing the two languages, they may develop their students' linguistic awareness of different aspects of both languages (Deller and Rinvolucri 2002). Also, the use of students' L1 may prove useful as it provides a short-cut for giving instructions and explanations where the cost of the L2 is too great; it builds up interlinked L1 and L2 knowledge in the students' minds (Cook 2001b, 418). Similarly, Ostovar-Namaghi and Norouzi $(2015,620)$ suggest the use of the students' mother tongue, if necessary, to make students feel safe if they cannot express themselves fully in L2 and as a background to the activities for teaching the four language skills (i.e., reading, listening, speaking and writing). Further, L1 can be used to avoid potential misunderstandings, to help students with comprehension if the explanation in L2 is ineffective, to facilitate different language learning strategies and to raise students' metacognitive awareness, etc. (Ostovar-Namaghi and Norouzi 2015).

When foreign language teaching and learning occurs in a classroom setting, a great deal of interaction/communication takes place between the students and the teacher as well as between the students themselves. In class, communication between the teacher and the students occurs for 'language teaching' purposes, or for 'class management' purposes. For example, the teachers' use of language for 'language teaching' purposes may include explaining lesson aims and learning objectives, giving task instructions, explaining language-related issues such as grammar, vocabulary, functions, or checking comprehension, etc. As regards 'class management' purposes, the teacher uses language, for example, to build a rapport with the students, to discuss administrative issues related to class and so on. The communication between students themselves mainly revolves around language learning activities (e.g., speaking tasks, teamwork or pair- 
work communication) but it also addresses other course-related issues. In an EFL class, this communication can be carried out primarily in English, but some of it can also be conducted in the students' L1. The choice of L1 use in different situations in the classroom setting depends on a number of factors, including the purpose of communication, the teacher's chosen method of foreign language teaching, the students' English language (as a foreign language) proficiency and their learning styles as well as students' attitudes towards learning English and a variety of emotional and psychological aspects (e.g., students' fear of making mistakes, discomfort, anxiety, motivation, etc.).

\subsection{Research Questions}

Based on the above considerations and previous research into the topic under discussion, and taking into account the context of our study (i.e., the use of Slovene as the students' L1 in teaching and learning Business English at tertiary level), our research was carried out to answer the following research questions:

RQ1: What are the students' opinions regarding the overall use of Slovene and English and the teacher's use of Slovene and English in class in different situations?

RQ2: What are the students opinions regarding the impact of the use of English and Slovene on their learning of Business English?

RQ3: What are the students' views about their own use of Slovene in a Business English class?

\section{The Study}

\subsection{Study Participants}

The participants in this study were the first-year, second-year and third-year students of economics and business (i.e., undergraduate university programme 'Economics and Business Studies' - BUN; BUN1, BUN2, BUN3) and of business administration (i.e., undergraduate higher professional education programme 'Business Administration' - BVS; BVS1, BVS2, BVS3) ${ }^{1}$ at the Faculty of Economics and Business, the University of Maribor. The total number of students taking part in this study was 174 (BUN1 - 31, BUN2 - 24, BUN3 - 14; BVS1 - 31, BVS2 - 31, BVS3 - 43). One-hundred and eleven (111) students were female and 63 were male. Their average age was 21.05 years. The students had Business English as their selected foreign language.

\subsection{Data Collection and Analysis}

The data for this study was collected via a questionnaire. The design of the questionnaire was based on the existing questionnaires on the use of mother tongue in foreign language classrooms (Liao 2006; Al Sharaeai 2012; Calis and Dikilitas 2012; Mutlu and Bayram and Demirbüken 2015). The adaptations to the existing questionnaires were made primarily in that we focused on Business English and not on general English.

The students enrolled in the BUN programme, have, on average, a higher level of English language knowledge than the students enrolled in the BVS programme. 
In order to identify the opinions of our students regarding the use of Slovene in the teaching and learning of Business English, the students were asked to give their opinions on a number of statements concerning various aspects of mother tongue use by teachers and by students both in class and when studying. The total number of statements was 23 . For these statements, a 5 -point Likert scale was used $(1=$ totally disagree, $2=$ disagree; $3=$ partially agree $; 4=$ agree $; 5=$ totally agree). In addition, the students had to state the perceived level of their Business English knowledge. The two demographic questions in the questionnaire were gender and age. The questionnaire was administered in the summer semester of the academic year 2015/2016.

Statistical analysis was performed using SPSS software (version 21). The questionnaire's internal consistency reliability was calculated by using Cronbach's alpha coefficient. The results of this analysis showed that the questionnaire was reliable (Cronbach Alpha $=.755)$.

\section{Results and Discussion}

In this section, we present and discuss the results of our analysis of the students' attitudes towards the use of Slovene in teaching and learning Business English.

For each set of statements related to our research questions, we ran ANOVA tests in order to see if there were any statistically significant differences in the students' responses among the six groups of students (i.e., BUN1, BUN2, BUN3, BVS1, BVS2, and BVS3). This was necessary due to the differences among the groups of students in terms of their level of English language knowledge. Apart from the analysis of the degree of students' agreement with the statements in the questionnaire, we also performed correlation analyses (Pearson product-moment coefficient) and cross-tabulations to establish any potential links between them. The results are presented and discussed for each research question separately.

\subsection{Research Question 1}

The first research question (RQ1) aimed to establish two things: i.e., the students' opinions regarding the overall use of Slovene in Business English class and their opinions regarding the teacher's use of Slovene and English in different situations. The students had to state their degree of agreement with the following statements:

S1: Business English lectures should be entirely in English (neither the students nor the teacher should use Slovene).

S16: I would like my teacher to use as little Slovene as possible during Business English classes.

S17: I prefer if my Business English teacher uses Slovene in class when we discuss matters related to class and not to the course contents (e.g., setting dates, administrative matters, etc.).

S18: I prefer if my Business English teacher uses Slovene in class when she gives task instructions (course contents related tasks).

The ANOVAs for this set of statements revealed that there were significant differences $(\mathrm{p}<.5)$ among the responses of the six groups of students participating in our study. This is why we present and comment on the results for each statement separately. The average degrees of agreement with the statements related to RQ1 are presented in Table 1 below. 
TABLE I. Students' opinions regarding the use of Slovene and English in Business English class in different situations, $\mathrm{N}=174$.

\begin{tabular}{|c|c|c|c|c|c|c|c|c|c|c|c|c|}
\hline & \multicolumn{2}{|c|}{$\begin{array}{l}\text { BUN1 } \\
(n=31)\end{array}$} & \multicolumn{2}{|c|}{$\begin{array}{l}\text { BUN2 } \\
(\mathrm{n}=24)\end{array}$} & \multicolumn{2}{|c|}{$\begin{array}{l}\text { BUN3 } \\
(n=14)\end{array}$} & \multicolumn{2}{|c|}{$\begin{array}{c}\text { BVS1 } \\
(\mathrm{n}=31)\end{array}$} & \multicolumn{2}{|c|}{$\begin{array}{c}\text { BVS2 } \\
(n=31)\end{array}$} & \multicolumn{2}{|c|}{$\begin{array}{c}\text { BVS3 } \\
(\mathrm{n}=43)\end{array}$} \\
\hline & M & SD & $\mathrm{M}$ & SD & $\mathrm{M}$ & SD & $\mathrm{M}$ & SD & $\mathrm{M}$ & SD & $\mathrm{M}$ & SD \\
\hline $\begin{array}{l}\text { S1: English } \\
\text { only for } \mathrm{T} \\
\& \text { Ss }\end{array}$ & ๗ે & $\stackrel{n}{\widehat{\sigma}}$ & $\stackrel{\infty}{\stackrel{n}{n}}$ & $\stackrel{+}{\widehat{\sigma}}$ & $\begin{array}{l}\text { ○ } \\
\dot{r}\end{array}$ & $\stackrel{8}{\stackrel{\rho}{\prime}}$ & $\hat{\wedge}$ & $\stackrel{\Xi}{\Xi}$ & $\begin{array}{l}\hat{\infty} \\
\stackrel{i}{ }\end{array}$ & $\stackrel{\infty}{\rightleftharpoons}$ & $\stackrel{\circ}{\stackrel{0}{\gamma}}$ & ঙ̦ \\
\hline $\begin{array}{l}\text { S16: T uses } \\
\text { ENG as } \\
\text { little use } \\
\text { of SLO as } \\
\text { possible }\end{array}$ & $\stackrel{\text { సे }}{\grave{n}}$ & $\stackrel{n}{\widehat{\sigma}}$ & $\underset{\dot{n}}{\hat{n}}$ & @ & $\stackrel{\Re}{\stackrel{\leftrightarrow}{\sim}}$ & $\begin{array}{l}N \\
\infty \\
\infty\end{array}$ & 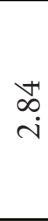 & $\stackrel{n}{\stackrel{n}{\rightleftarrows}}$ & $\stackrel{\curvearrowright}{\mathrm{i}}$ & ๙ุ & $\stackrel{\stackrel{N}{~}}{\mathrm{~N}}$ & 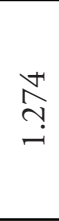 \\
\hline $\begin{array}{l}\text { S17: T uses } \\
\text { SLO_ class } \\
\text { matters }\end{array}$ & $\begin{array}{l}\vec{\sigma} \\
\dot{r}\end{array}$ & $\begin{array}{l}\stackrel{\ddots}{\beth} \\
\rightleftharpoons\end{array}$ & $\vec{\sim}$ & $\stackrel{n}{\stackrel{n}{\sim}}$ & $\stackrel{\hat{r}}{\dot{m}}$ & $\underset{\overbrace{}}{\stackrel{\Xi}{\leftrightarrows}}$ & $\begin{array}{l}\hat{\infty} \\
\dot{n}\end{array}$ & 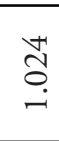 & $\stackrel{0}{\rightarrow}$ & $\stackrel{\infty}{\underset{ユ}{ت}}$ & $\underset{n}{n}$ & $\stackrel{\vartheta}{\stackrel{\ddots}{\rightleftarrows}}$ \\
\hline $\begin{array}{l}\text { S18: T uses } \\
\text { SLO_task } \\
\text { instructions }\end{array}$ & ๙ุ & $\underset{\infty}{\infty}$ & 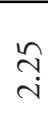 & ๙ิ & 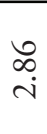 & 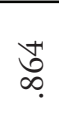 & $\tilde{n}$ & 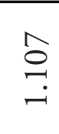 & $\stackrel{m}{\infty}$ & $\stackrel{\infty}{Ð}$ & $\tilde{n}$ & ஓ \\
\hline
\end{tabular}

Table 1 shows that, overall, BUN students agreed to a higher degree than BVS students that Business English classes should be carried out in English only and that Slovene should not be used at all. The highest average degree of agreement with the belief that Business English classes should be delivered in English only (S1) was observed with the BUN2 group, followed by the BUN1 group. On the other side of the scale, the lowest degree of agreement was observed with BVS3 students, followed by BVS1 students. The post hoc ANOVA test for these statements (Turkey HSD) revealed that the opinions of students in the BUN2 group were significantly different from the opinions of the BVS3 group $(\mathrm{r}=.809, \mathrm{p}<.05)$.

Table 1 also shows that the students in the BUN2 group would prefer their teacher to use Slovene in class as little as possible (S16) the most, followed by BUN3 students, and that BVS3 students would tend to disagree with this statement the most, followed by BVS2 students, which is in a way consistent with the results obtained for S1. This was also confirmed by the post hoc ANOVA test (Turkey HSD), which showed a significant difference between the opinions of BUN2 students and of BVS2 $(r=.892, \mathrm{p}<.05)$ and BVS3 students $(\mathrm{r}=.922, \mathrm{p}<.05)$.

As regards the teacher's use of Slovene for talking about class-related matters such as administration (S17), we found that BVS1 and BVS3 students would prefer such matters to be discussed in Slovene the most, while BUN2 and BVS2 students would like this the least. However, we should point out that all the average scores are above 3 for all groups, which means that the students would either partly agree or agree with the statement $(\mathrm{N}=174$, overall $\mathrm{M}=3.54$, overall $\mathrm{SD}=1.146$ ). The post hoc ANOVA test (Turkey HSD) did not reveal any statistically significant differences among the groups' responses to this statement.

Looking at the students' attitudes towards the teacher's use of Slovene when giving task instructions (S18), we found that, on average, BVS students would much rather receive these instructions in 
Slovene than BUN students, who would prefer their teacher to give task instructions in English and not in Slovene. The post hoc ANOVA test (Turkey HSD) showed a statistically significant difference between the BUN2 and BVS1 group $(\mathrm{r}=-1.073, \mathrm{p}<.05)$ and between the BUN2 and BVS3 group $(\mathrm{r}=-1.099, \mathrm{p}<.05)$.

Studying the significant positive correlations between the statements related to RQ1 (Pearson product-moment coefficient), we found, among other things, that those students whose overall opinion was that neither the students nor the teacher should use Slovene during Business English lectures (S1) also agreed that their teacher should use as little Slovene as possible during class (S16) (BUN1: $\mathrm{r}=.436, \mathrm{p}<.05$; BUN2: $\mathrm{r}=.0641, \mathrm{p}<.001$; BVS1: $\mathrm{r}=.667, \mathrm{p}<.001$; BVS2: $\mathrm{r}=.545$, $\mathrm{p}<.001$; BVS3: $r=.779, \mathrm{p}<.001)$. On the other hand, the negative correlations established between the statements related to RQ1 were that those students who would prefer their teacher to use as little Slovene as possible (S16) would not wish their teacher to use Slovene when talking about courserelated matters (S17), which was statistically significant in the BUN2 group $(\mathrm{r}=-.719, \mathrm{p}<.001)$. Similarly, those students who would prefer their teacher to use predominantly English (S16) would not wish to receive task instructions in Slovene (S18) (BUN1: r=-.360, p<0.5; BUN3: $\mathrm{r}=-.438, \mathrm{p}<0.5$; BVS1: $\mathrm{r}=-.478, \mathrm{p}<.001$; BVS3: $\mathrm{r}=-.707, \mathrm{p}<.001)$. In addition, the students in BVS1, BVS2 and BVS3 groups who would like English-only classes (S1) disliked the fact that the teacher would give task instructions in Slovene (S18)(BVS1: $r=-.424, \mathrm{p}<0.5$; BVS2: $\mathrm{r}=-.423$, $\mathrm{p}<0.5$; BVS3: $\mathrm{r}=-.787, \mathrm{p}<.001$ ), which in fact makes sense as these two approaches contrast.

Apart from these correlations, we established significant positive correlations between the statements S17 and S18. That is, those students who preferred that the teacher used Slovene when matters related to class and not to course contents were discussed (S17) also preferred that the teacher give task instructions in Slovene (S18). This correlation was statistically significant for the BUN2 group $(\mathrm{r}=.719, \mathrm{p}<.001)$, BVS1 group $(\mathrm{r}=.449, \mathrm{p}<.05)$, BVS2 group $(\mathrm{r}=.644$, $\mathrm{p}<.001)$ and BVS3 group $(\mathrm{r}=.718, \mathrm{p}<.001)$.

Based on these results obtained in relation to RQ1, we can place our students into two groups, i.e., those students who prefer that their teacher uses English only in Business English class (or at least as little Slovene as possible) and those who would welcome the use of Slovene in class (e.g., for giving task instructions and for discussing class and course-related administrative matters). To find the reason for these two distinct groups, we looked at whether the students' perceived level of their Business English (BE) knowledge was an influencing factor. There was a significant correlation between the students' perceived level of their BE knowledge and the opinion that the BE teacher should use English only (S1). We found that those students who considered their knowledge of Business English to be very good or excellent were also more inclined to having English-only classes than those who rated their knowledge of Business English as very bad or bad. Out of all 6 groups, BUN2 students were the strongest as regards their level of English language proficiency.

\subsection{Research Question 2}

The second research question (RQ2) addressed the beliefs of students regarding the impact which the use of Slovene and English in class has on their learning of Business English. The statements in the questionnaire referring to this question were:

S2: BE teacher should use English and Slovene during classes because this facilitates my understanding of the lecture's contents. 
S3: The use of Slovene during BE classes reduces the amount of BE that I receive in class and I do not like this.

S4: Slovene should be used in Business English classes because it is important to be aware of the differences between English and Slovene.

S6: I am motivated to learn Business English if the teacher uses only English during BE classes.

S12: I learn the contents of BE lessons faster if the teacher uses English only.

Similar to the statements for RQ1, the ANOVA tests revealed some statistically significant differences in the answers among the six groups of students in our study. For that reason, the data is again presented for each statement and group separately (see Table 2).

TABLE 2. Students' beliefs about the impact the use of Slovene and English in class has on their learning of Business English, N=174.

\begin{tabular}{|c|c|c|c|c|c|c|c|c|c|c|c|c|}
\hline & \multicolumn{2}{|c|}{$\begin{array}{l}\text { BUN1 } \\
(\mathrm{n}=31)\end{array}$} & \multicolumn{2}{|c|}{$\begin{array}{l}\text { BUN2 } \\
(\mathrm{n}=24)\end{array}$} & \multicolumn{2}{|c|}{$\begin{array}{l}\text { BUN33 } \\
(\mathrm{n}=14) \\
\end{array}$} & \multicolumn{2}{|c|}{$\begin{array}{l}\text { BVS1 } \\
(\mathrm{n}=31)\end{array}$} & \multicolumn{2}{|c|}{$\begin{array}{c}\text { BVS2 } \\
(\mathrm{n}=31) \\
\end{array}$} & \multicolumn{2}{|c|}{$\begin{array}{c}\text { BVS3 } \\
(\mathrm{n}=43) \\
\end{array}$} \\
\hline & $\mathrm{M}$ & SD & $\mathrm{M}$ & SD & M & SD & $M$ & SD & $\mathrm{M}$ & SD & $\mathrm{M}$ & SD \\
\hline $\begin{array}{l}\text { S2: T's use } \\
\text { of ENG + } \\
\text { SLO / com- } \\
\text { prehension }\end{array}$ & $\begin{array}{l}\stackrel{n}{f} \\
\dot{m}\end{array}$ & 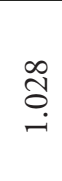 & $\stackrel{\text { ¿ }}{\curvearrowright}$ & $\stackrel{8}{\longrightarrow}$ & $\begin{array}{l}\stackrel{\cap}{+} \\
\stackrel{+}{+}\end{array}$ & 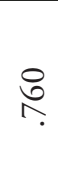 & $\stackrel{\bigcirc}{\stackrel{\longrightarrow}{+i}}$ & $\stackrel{\infty}{\stackrel{+}{+1}} \underset{\sim}{\sim}$ & $\stackrel{?}{\stackrel{H}{H}}$ & $\begin{array}{l}\infty \\
\infty \\
0 \\
-\end{array}$ & $\begin{array}{l}\infty \\
\infty \\
\dot{r}\end{array}$ & 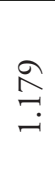 \\
\hline $\begin{array}{l}\text { S3: T's use } \\
\text { of SLO_less } \\
\text { ENG input } \\
=\text { dislike }\end{array}$ & $\begin{array}{l}\hat{\infty} \\
i \\
i\end{array}$ & 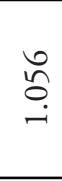 & 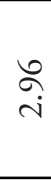 & $\stackrel{\triangleq}{\tilde{n}}$ & & $\stackrel{\text { }}{\sigma}$ & $\stackrel{m}{i}$ & $\hat{n}$ & $\stackrel{n}{\stackrel{n}{i}}$ & ণิ & $\begin{array}{l}\stackrel{i}{0} \\
\text { i }\end{array}$ & $\stackrel{n}{\rightleftarrows}$ \\
\hline $\begin{array}{l}\text { S4: } \\
\text { SLO_ENG } \\
\text { differences } \\
\text { awareness }\end{array}$ & $\stackrel{0}{\stackrel{0}{m}}$ & $\stackrel{m}{8}$ & $\stackrel{\searrow}{\stackrel{i}{i}}$ & 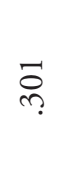 & $\stackrel{m}{\dot{m}}$ & $\hat{\sigma}$ & $\stackrel{+}{\dot{n}}$ & ๙ิ & $\stackrel{\vec{n}}{\dot{n}}$ & $\stackrel{\hat{\sigma}}{\text { है }}$ & $\underset{i}{\stackrel{丶}{r}}$ & $\begin{array}{l}\stackrel{+}{\circ} \\
\curvearrowleft\end{array}$ \\
\hline $\begin{array}{l}\text { S6: ENG } \\
\text { only } \\
\text { motivation } \\
\text { to learn }\end{array}$ & $\begin{array}{l}\stackrel{n}{n} \\
\dot{m}\end{array}$ & 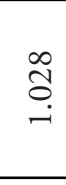 & $\underset{\dot{r}}{\hat{r}}$ & 守 & 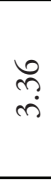 & $\underset{\infty}{\stackrel{f}{~}}$ & $\begin{array}{l}\widetilde{N} \\
\sim\end{array}$ & 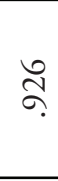 & $\hat{\widehat{i}}$ & ڤి & $\begin{array}{l}\vec{\infty} \\
\stackrel{i}{i}\end{array}$ & $\stackrel{\infty}{\rightarrow}$ \\
\hline $\begin{array}{l}\text { S12: ENG } \\
\text { only_learn } \\
\text { BE contents } \\
\text { faster }\end{array}$ & $\begin{array}{l}\overrightarrow{0} \\
\vec{m}\end{array}$ & $\begin{array}{l}8 \\
\infty \\
\infty\end{array}$ & $\underset{\dot{\theta}}{\hat{\theta}}$ & $\hat{\sigma}$ & $\stackrel{\vec{n}}{\tilde{m}}$ & $\begin{array}{l}\text { Oे } \\
\infty\end{array}$ & $\begin{array}{l}\sqrt{6} \\
i \\
\text {. }\end{array}$ & م્ & $\stackrel{8}{\stackrel{8}{n}}$ & $\stackrel{\text { Iิ }}{\stackrel{乛}{ت}}$ & $\begin{array}{l}\vec{\infty} \\
\vec{i}\end{array}$ & 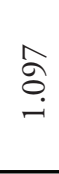 \\
\hline
\end{tabular}

As we can see in Table 2, the BUN3 group considered the use of Slovene by the teacher as a very important factor for their comprehension of the course contents (S2), followed by the BVS2 and BVS1 groups. This could be due to the fact that the BUN3 course is delivered at C1 (CEFR) level, which some students may find challenging. On the other hand, the students in BUN2 group did not perceive the teacher's use of Slovene as something which would facilitate their comprehension of the contents of BE lectures. The post hoc ANOVA test (Turkey HSD) for this 
statement revealed significant differences between the responses of the BUN3 group and BUN1 group $(\mathrm{r}=.048, \mathrm{p}<.05)$ and BUN3 group and BUN2 group $(\mathrm{r}=1.542, \mathrm{p}<.05)$; BUN2 group and BVS1 group $(\mathrm{r}=-1.138,<.05)$, BUN2 group and BVS2 group $(\mathrm{r}=-1.171, \mathrm{p}<.05)$, BUN2 group and BVS3 group $(\mathrm{r}=-.925, \mathrm{p}<0.5)$.

In connection with the amount of English language input in class (S3), we observed that BUN3 students did not dislike the teacher's use of Slovene. On the other hand, BUN2 and BUN1 groups disliked the fact that the teacher's use of Slovene reduces the amount of Business English they are exposed to in class. The ANOVA post hoc test (Turkey HSD) for this statement, however, did not reveal any statistically significant differences among the six groups.

The BUN1 and BUN2 groups were the only groups that did not consider the use of Slovene in Business English class as an important factor in raising awareness of the differences between English and Slovene. The average scores of these two groups were significantly lower than those of the other four groups. Significant differences in responses were thus observed between the BUN1 group and BVS1 group $(\mathrm{r}=-.774, \mathrm{p}<0.5)$, and between the BUN2 group and BVS1 group ( $\mathrm{r}=-.977, \mathrm{p}<0.5)$ (Turkey HSD). Both BVS1 and BUN3 students agreed the most with the statement that Slovene should be used in order to raise awareness of the differences between English and Slovene.

Overall, BUN groups demonstrated higher degrees of agreement with the statement that the teacher's English-only approach in BE lessons is a motivator for learning Business English (S6) to those of BVS groups. Again, there were differences between the average scores per group, i.e., BUN1 average was significantly different to the BVS1 average $(r=.935, p<0.5)$, while the BUN2 average differed significantly from the BVS1 average $(\mathrm{r}=1,151, \mathrm{p}<.05)$ and BVS3 average $(\mathrm{r}=.853, \mathrm{p}<.05)$ (Turkey HSD).

Regarding the speed of learning the contents of BE lessons faster if the teacher uses English only (S12), we found that the BUN groups reported a higher level of agreement with this statement than the BVS groups, with BUN2 being at the top and BVS1 at the bottom. The difference in the responses was statistically significant between the BUN2 group and BVS1 group ( $r=1.022$, $\mathrm{p}<0.5)$ and BVS3 group $(\mathrm{r}=.853, \mathrm{p}<0.5)$ (Turkey HSD).

To gain further insight into the students' perceptions regarding the impact which the use of Slovene and English in class has on their learning of Business English in general, we performed a set of correlation analyses for each group of students (Pearson product-moment coefficient). We found a number of both positive and negative correlations between the statements for each group. We established that the students who considered the teacher's use of Slovene as the facilitator of their understanding of the lesson's contents (S2) also agreed that Slovene should be used to raise awareness of the differences between English and Slovene (S4) (BUN1: r=.574, p<.01; BUN2: $\mathrm{r}=.431, \mathrm{p}<.05 ;$ BUN3: $\mathrm{r}=.781, \mathrm{p}<.01 ;$ BVS1: $\mathrm{r}=.545, \mathrm{p}<.01 ; \mathrm{BVS} 2: \mathrm{r}=.506, \mathrm{p}<.01$; BVS3: $\mathrm{r}=.743, \mathrm{p}<.01)$. On the other hand, the students who were motivated to learn BE because the teacher uses only English (S6) also reported that they learn the contents of BE lessons faster if the teacher uses only English (S12) (BUN1: $\mathrm{r}=.631, \mathrm{p}<.01$; BUN2; $\mathrm{r}=.648, \mathrm{p}<.01$; BUN3: $\mathrm{r}=.676$, $\mathrm{p}<.01$; BVS1: $\mathrm{r}=.422, \mathrm{p}<.05$; BVS2: $\mathrm{r}=.614, \mathrm{p}<.01$; BVS3: $\mathrm{r}=.524, \mathrm{p}<.01)$.

On the other hand, we found that in four out of six groups, the students who were motivated to learn Business English because the teacher uses only English in class (S6) would disagree that Slovene facilitates their understanding of lesson contents (S2) (BUN1: r=-.484, p<.01; 
BVS1=r=-.448, $\mathrm{p}<.05$; BVS2: $\mathrm{r}=-.538, \mathrm{p}<.01$; BVS3: $\mathrm{r}=-.615, \mathrm{p}<.01)$. Some students also disliked the teacher's use of Slovene as it reduced the amount of English they receive in class (S6 and S3) (BUN1: r=516, p<.01; BUN2: r=.701, p<.01; BVS2: r=.497, $\mathrm{p}<.01$; BVS3: $\mathrm{r}=.742$, $\mathrm{p}<.01)$. Similarly, those students who disliked the fact that the teacher's use of Slovene reduced the amount of English language input they receive in class (S3) did not consider it important to have the differences between English and Slovene pointed out (S4) (BUN1: $r=-.451, \mathrm{p}<.01$; BUN2: $r=-.529, \mathrm{p}<.01$; BVS1:r=-.497, $\mathrm{p}<.01$; BVS2: $\mathrm{r}=-.424, \mathrm{p}<.05$; BVS3: $\mathrm{r}=-.633, \mathrm{p}<.01$ ). The students who are motivated to learn Business English because their teacher uses English only in class (S6), tended to dislike the use of Slovene as a way of pointing out the differences between English and Slovene (S4) (BUN1: $r=-.429, \mathrm{p}<.05$; BUN2: $\mathrm{r}=-.488$; $\mathrm{p}<.05$; BVS1: $\mathrm{r}=-.563$, $\mathrm{p}<.01$; BVS2: $\mathrm{r}=-.524, \mathrm{p}<.001$; BVS3: $\mathrm{r}=-.532, \mathrm{p}<.01)$.

Similar to our findings on the first research question, we also established that we can divide the students into two distinct groups. Again, there was the 'English only' group that considered the 'English only' approach to be a positive motivating factor for learning Business English. They agreed that they learn Business English faster this way, but they also saw no need for the differences between English and Slovene to be highlighted in class. The other group, i.e., the group that would not be against the use of Slovene in class, considered it important to be aware of the differences between the two languages. Also, they agreed that the use of Slovene in class facilitates their understanding of contents addressed within the Business English course. Similar to RQ1, the students' perceived level of their Business English language knowledge was a factor which influenced their attitudes towards the use of English and/or Slovene in class. That is, the students with a perceived higher level of BE tended to lean towards the 'English only' classes.

\subsection{Research Question 3}

The third research question (RQ3) focused on the attitudes of students towards and their use of Slovene or English during Business English lessons. For this question, two groups of statements had to be rated: (a) the statements concerning the students' attitudes towards their use of Slovenel English in class, and (b) the statements concerning their actual use of Slovene /English in class. The statements included in the questionnaire to determine our students' attitudes towards their use of Slovene/English in class are given below. The results for these two groups of statements are presented in Table 3 and Table 4.

(a) Students' attitudes towards their use of Slovene /English in class

S5: During lessons, the BE teacher should allow the students to express themselves in Slovene when they feel that they cannot express themselves adequately in English (e.g., during discussions).

S7: I feel under pressure when I have to use English only during Business English classes.

S8: I feel less stressed if the BE teacher occasionally uses Slovene during class to explain something.

S9: I feel strange if I have to speak in English with my classmates when we do group assignments in class, even when tasks are 'discuss the topic'/discuss the advantages and disadvantages of $\mathrm{xxx}^{\prime}$.

S10: I want to be able to speak Slovene during BE classes when I feel that I need to. 
S11: The BE teacher should insist that the students use only English during lessons (should make us use English only).

S15: It is not important that I speak only English in class as long as I complete all the tasks that I have to.

TABLE 3. Students' attitudes towards their use of Slovene / English in class, N=174.

\begin{tabular}{|c|c|c|c|c|c|c|c|c|c|c|c|c|}
\hline & \multicolumn{2}{|c|}{$\begin{array}{l}\text { BUN1 } \\
(\mathrm{n}=31)\end{array}$} & \multicolumn{2}{|c|}{$\begin{array}{l}\text { BUN2 } \\
(n=24)\end{array}$} & \multicolumn{2}{|c|}{$\begin{array}{l}\text { BUN3 } \\
(n=14)\end{array}$} & \multicolumn{2}{|c|}{$\begin{array}{l}\text { BVS1 } \\
(\mathrm{n}=31)\end{array}$} & \multicolumn{2}{|c|}{$\begin{array}{c}\text { BVS2 } \\
(\mathrm{n}=31)\end{array}$} & \multicolumn{2}{|c|}{$\begin{array}{l}\text { BVS3 } \\
(n=43)\end{array}$} \\
\hline & $\mathrm{M}$ & SD & $\mathrm{M}$ & SD & $\mathrm{M}$ & SD & $\mathrm{M}$ & SD & $\mathrm{M}$ & SD & $\mathrm{M}$ & SD \\
\hline $\begin{array}{l}\text { S5: Teacher } \\
\text { allows Ss use } \\
\text { SLO (need) }\end{array}$ & $\stackrel{\infty}{\stackrel{\infty}{n}}$ & ळ. & $\begin{array}{l}\hat{\sigma} \\
i\end{array}$ & $\hat{\sigma}$ & $\begin{array}{l}\stackrel{n}{n} \\
\dot{n}\end{array}$ & $\underset{\sigma}{\tilde{\sigma}}$ & $\stackrel{\infty}{\stackrel{\infty}{n}}$ & ڤ̊ & $\stackrel{\infty}{\sim}$ & $\stackrel{\varrho}{\rightleftarrows}$ & $\underset{\dot{m}}{\stackrel{\curvearrowright}{r}}$ & $\begin{array}{l}\infty \\
\stackrel{\infty}{0} \\
\stackrel{0}{-}\end{array}$ \\
\hline $\begin{array}{l}\text { S7: Use ENG } \\
\text { only }=\text { pressure }\end{array}$ & $\stackrel{\text { ì }}{i}$ & $\stackrel{n}{n}$ & $\vec{\sim}$ & $\stackrel{+r}{\stackrel{+}{f}}$ & $\begin{array}{l}\infty \\
i\end{array}$ & $\stackrel{0}{\stackrel{0}{0}}$ & $\stackrel{m}{m}$ & $\tilde{n}$ & $\stackrel{\pi}{\pi}$ & ్ֶరి & $\vec{n}$ & 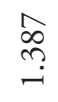 \\
\hline $\begin{array}{l}\text { S8: Occasional } \\
\text { use of SLO = } \\
\text { feel less stressed }\end{array}$ & $\tilde{n}$ & $\stackrel{\rightleftarrows}{\rightleftarrows}$ & $\stackrel{n}{i}$ & $\overrightarrow{\widehat{n}}$ & $\stackrel{\curvearrowright}{\dot{r}}$ & $\begin{array}{l}\sqrt{n} \\
\stackrel{n}{n}\end{array}$ & 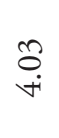 & $\stackrel{0}{\leftrightarrows}$ & $\stackrel{\overbrace{}}{\circ}$ & $\stackrel{0}{0}$ & $\begin{array}{l}+\infty \\
\infty \\
\dot{n}\end{array}$ & $\stackrel{2}{=}$ \\
\hline $\begin{array}{l}\text { S9: ENG }= \\
\text { strange group } \\
\text { discussions }\end{array}$ & $\stackrel{+}{i}$ & 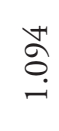 & $\overrightarrow{\vec{i}}$ & $\begin{array}{l}\widehat{\sigma} \\
\stackrel{-}{-}\end{array}$ & $\begin{array}{l}\infty \\
\infty \\
i\end{array}$ & $\stackrel{\overbrace ָ}{\widetilde{\gamma}}$ & $\stackrel{\Delta \leftrightarrow}{\Delta}$ & 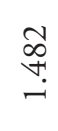 & $\begin{array}{l}\stackrel{0}{\vec{r}} \\
\text { r. }\end{array}$ & 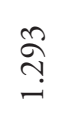 & $\begin{array}{l}\stackrel{f}{+} \\
\dot{n}\end{array}$ & $\stackrel{\hat{\sigma}}{-}$ \\
\hline $\begin{array}{l}\text { S10: Use SLO } \\
\text { if need }\end{array}$ & ले & $\stackrel{\widehat{\sigma}}{.}$ & $\underset{\substack{n \\
i}}{ }$ & 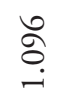 & \begin{tabular}{l}
\multirow{r}{*}{} \\
$\dot{m}$
\end{tabular} & $\stackrel{\overbrace{}}{\stackrel{N}{ت}}$ & $\stackrel{+r}{\stackrel{m}{n}}$ & $\stackrel{n}{\leftrightarrows}$ & $\overrightarrow{\hat{n}}$ & 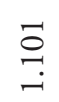 & $\underset{\dot{m}}{\hat{n}}$ & 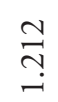 \\
\hline $\begin{array}{l}\text { S11: T insists } \\
\text { on Ss use ENG } \\
\text { only }\end{array}$ & $\begin{array}{l}\dot{\theta} \\
\dot{m}\end{array}$ & $\stackrel{\infty}{\infty}$ & $\begin{array}{l}\tilde{r} \\
\dot{n}\end{array}$ & 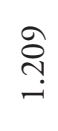 & $\vec{i}$ & & $\begin{array}{l}\stackrel{n}{N} \\
\stackrel{N}{*}\end{array}$ & $\overrightarrow{\vec{J}}$ & $\begin{array}{l}\vec{\infty} \\
\text { i }\end{array}$ & 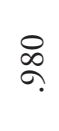 & $\begin{array}{l}\stackrel{0}{i} \\
\text {. }\end{array}$ & $\stackrel{\vec{N}}{\stackrel{\sim}{\sim}}$ \\
\hline $\begin{array}{l}\text { S15: Can use } \\
\text { SLO if tasks } \\
\text { completed }\end{array}$ & 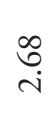 & $\hat{\hat{o}}$ & $\stackrel{\sim}{\sim}$ & $\stackrel{m}{=}$ & $\stackrel{\grave{n}}{\dot{n}}$ & $\stackrel{\#}{\sigma}$ & $\stackrel{\text { ft. }}{\text { d. }}$ & $\overrightarrow{\widetilde{n}}$ & $\stackrel{m}{m}$ & 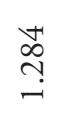 & 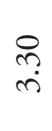 & ڤ̂̀ \\
\hline
\end{tabular}

On average, BVS students felt under greater pressure if they were forced to use English only in class (S7), which was most evident in the BVS3 group. On the other hand, BUN students would not feel under pressure in the same situation. The post hoc tests (Turkey HSD) revealed statistically significant differences between the BUN2 and BVS2 group $(r=-1.114, p<.05)$ and between the BUN2 and BVS3 group $(r=-1.303, p<0.5)$. These results are consistent with the fact that the occasional use of Slovene in class would make students feel less stressed (S8). This is especially true for the BVS1 and BVS2 groups. Interestingly, only BVS2 and BVS3 students would feel odd if they had to speak in English during group discussions (S9). This is surprising since the aim of these activities is to practice speaking and enhance students' fluency in English. Their responses were significantly different from the responses of BUN2 students (BVS2: $\mathrm{r}=-.995, \mathrm{p}<.05$; BVS3: $\mathrm{r}=-1.298, \mathrm{p}<.05)$. 
Almost all groups except the BUN2 (and partially BUN1) group would prefer to be able to use Slovene when they feel that it is necessary (S10). The inclination to use Slovene was more evident in BVS groups and it was also strong in the BUN3 group. Similar results were observed with S15, i.e., the students felt that their use of Slovene in class is acceptable as long as they complete all the tasks. Again, BUN2 and BUN1 students did not seem to agree with this. BUN2 groups differentiated the most from the BVS1 group $(\mathrm{r}=-1.169, \mathrm{p}<.05)$ and BVS3 group $(\mathrm{r}=-1.052$, $\mathrm{p}<.05)$. Also, the same groups of students except the BUN2 group would prefer the teacher to allow students to use Slovene if they feel that they cannot express themselves adequately in English, e.g., during discussions (S5) (BUN2 and BVS1: $r=-.914, p<.05$; BUN2 and BVS2: $\mathrm{r}=-.914, \mathrm{p}<.05$; BUN2 and BVS3; $\mathrm{r}=-1.101, \mathrm{p}<.05)$, and only the BUN2 group was more likely to agree that the teacher should make students use English only during Business English lessons (S11). Here, the strongest and the most significant difference was again between the BUN2 group and BVS1 and BVS3 groups (BVS1: $\mathrm{r}=1.173$, $\mathrm{p}<.05$; BVS3: $\mathrm{r}=-1.067, \mathrm{p}<.05$ ).

(b) Students' actual use of Slovene /English in class:

S13: I tend to speak in Slovene rather than in English when we do group-work (or pairwork) in class.

S14: When we do group-work (or pair-work) in class, we talk to each other in Slovene because this makes us more efficient (e.g., we finish the task faster).

S19: When I have to say something in English during the lesson, I first think of what I want to say in Slovene and then I translate that into English.

S20: When I have to write in English, I first think of what I want to write about in Slovene and then I translate that into English.

S21: In a BE class, I speak Slovene to my classmates when I'm explaining a point in the lesson to them.

S22: In a BE class, I speak Slovene to my classmates when I need to ask them to explain a point in the lesson to me.

S23: If my classmates start talking to me in Slovene while we are working on a task in class, I still prefer (continue) to speak in English.

The results of students' responses regarding their actual use of Slovene and/or English in class are shown in Table 4.

On average, BVS3 and BUN3 students stated that they preferred to use Slovene when doing some activities in groups (or in pairs) the most; however, their inclination to do so did not differ in statistical significance from the other groups (Turkey HSD). The same was not the case with statement 14, where statistically significant differences were established between the BUN2 group and BVS3 group - BUN2 students would tend to disagree that the use of Slovene during group work activities would make them more efficient (average $=2.88$ ), whereas the BVS students would agree to this (average $=4.00=$ 'agree').

Regarding statement S19 (think first in Slovene then speak in English), BUN2 group's responses differed radically from the rest as they disagreed with this statement the most. Interestingly, BVS students (all three groups) would prefer this approach the most (among all six groups) with the BVS3 group leading, followed by the BVS1 group. Very similar results were observed with 
TABLE 4. Students' actual use of Slovene / English in Business English class, N= 174.

\begin{tabular}{|c|c|c|c|c|c|c|c|c|c|c|c|c|}
\hline & \multicolumn{2}{|c|}{$\begin{array}{l}\text { BUN1 } \\
(n=31)\end{array}$} & \multicolumn{2}{|c|}{$\begin{array}{l}\text { BUN2 } \\
(n=24)\end{array}$} & \multicolumn{2}{|c|}{$\begin{array}{l}\text { BUN3 } \\
(n=14) \\
\end{array}$} & \multicolumn{2}{|c|}{$\begin{array}{c}\text { BVS1 } \\
(n=31)\end{array}$} & \multicolumn{2}{|c|}{$\begin{array}{c}\text { BVS2 } \\
(n=31)\end{array}$} & \multicolumn{2}{|c|}{$\begin{array}{c}\text { BVS3 } \\
(\mathrm{n}=43)\end{array}$} \\
\hline & $\mathrm{M}$ & $\mathrm{SD}$ & $\mathrm{M}$ & SD & $\mathrm{M}$ & SD & $\mathrm{M}$ & SD & $\mathrm{M}$ & SD & $\mathrm{M}$ & SD \\
\hline $\begin{array}{l}\text { S13: Use } \\
\text { SLO in } \\
\text { group- } \\
\text { work }\end{array}$ & $\begin{array}{l}n \\
\tilde{n}\end{array}$ & $\begin{array}{l}\infty \\
\infty \\
\infty\end{array}$ & $\stackrel{\check{n}}{\sim}$ & กิ & $\stackrel{\Re}{\tilde{n}}$ & $\hat{\widehat{\sigma}}$ & $\begin{array}{l}\stackrel{\leftrightarrow}{\uplus} \\
\stackrel{n}{*}\end{array}$ & $\stackrel{\infty}{\stackrel{0}{0}}$ & $\begin{array}{l}\stackrel{n}{\forall} \\
\dot{n}\end{array}$ & $\stackrel{\beth}{\beth}$ & $\stackrel{N}{N}$ & $\stackrel{0}{\stackrel{0}{0}}$ \\
\hline $\begin{array}{l}\text { S14: SLO use } \\
\text { in group }= \\
\text { more efficient }\end{array}$ & $\tilde{n}$ & 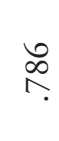 & $\begin{array}{l}\infty \\
\infty \\
i\end{array}$ & 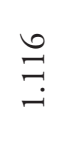 & $\hat{n}$ & $\stackrel{\infty}{\stackrel{n}{\rightleftarrows}}$ & $\begin{array}{l}\vec{\sigma} \\
\dot{n}\end{array}$ & 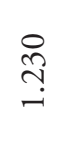 & $\begin{array}{l}\sqrt{6} \\
\dot{n}\end{array}$ & 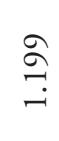 & $\underset{\forall}{8}$ & 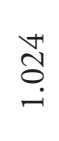 \\
\hline $\begin{array}{l}\text { S19: Think } \\
\text { first in SLO } \\
\text { than speak in } \\
\text { ENG }\end{array}$ & $\begin{array}{l}\stackrel{0}{\longrightarrow} \\
\dot{n}\end{array}$ & $\begin{array}{l}\curvearrowleft \\
\stackrel{\sim}{\rightleftarrows}\end{array}$ & $\begin{array}{l}\infty \\
0 \\
i\end{array}$ & 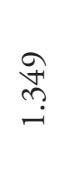 & $\stackrel{\overbrace{}}{\text { ஸे }}$ & 总 & $\tilde{n}$ & กิ & $\stackrel{m}{m}$ & $\begin{array}{l}\infty \\
\stackrel{n}{n}\end{array}$ & $\vec{\sigma}$ & $\begin{array}{l}\infty \\
\infty \\
\infty\end{array}$ \\
\hline $\begin{array}{l}\text { S20: Think } \\
\text { first in SLO } \\
\text { than write in } \\
\text { ENG }\end{array}$ & $\ddot{\sim}$ & กิ & $\stackrel{\curvearrowleft}{ָ}$ & ๗ิ & $\begin{array}{l}\stackrel{\cap}{n} \\
\dot{n}\end{array}$ & 華 & $\begin{array}{l}n \\
\tilde{n}\end{array}$ & 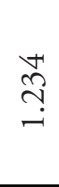 & $\begin{array}{l}\stackrel{n}{\forall} \\
\dot{m}\end{array}$ & $\stackrel{\Omega}{\check{N}}$ & $\underset{\forall}{8}$ & 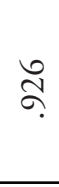 \\
\hline $\begin{array}{l}\text { S21: Use } \\
\text { SLO- } \\
\text { explain sth. } \\
\text { to classmates }\end{array}$ & $\underset{\forall}{8}$ & $\stackrel{+}{\circ}$ & $\stackrel{+r}{n}$ & సָ & $\begin{array}{l}\diamond \\
\infty \\
\dot{\sim}\end{array}$ & 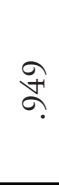 & $\begin{array}{l}\hat{\infty} \\
\dot{n}\end{array}$ & $\stackrel{\pi}{-}$ & $\begin{array}{l}\AA \\
\dot{m}\end{array}$ & $\begin{array}{l}\infty \\
\stackrel{\circ}{\circ}\end{array}$ & $\hat{\varrho}$ & ๙ิ \\
\hline $\begin{array}{l}\text { S22: Use } \\
\text { SLO to ask } \\
\text { classmates for } \\
\text { explanation }\end{array}$ & $\hat{\sigma}$ & $\stackrel{\infty}{\stackrel{+}{\sigma}}$ & $\underset{\forall}{\stackrel{\infty}{+}}$ & $\stackrel{\infty}{0}$ & 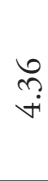 & $\underset{\infty}{\stackrel{1}{~}}$ & 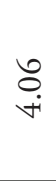 & 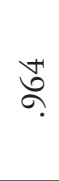 & $\underset{\overbrace{}}{0}$ & $\begin{array}{l}\stackrel{0}{\infty} \\
\infty\end{array}$ & $\underset{\forall}{\stackrel{t}{*}}$ & $\stackrel{\overbrace{}}{\curvearrowright}$ \\
\hline $\begin{array}{l}\text { S23: Insist } \\
\text { on ENG if } \\
\text { others use } \\
\text { SLO }\end{array}$ & $\hat{\overbrace{}}$ & 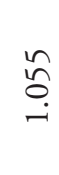 & $\begin{array}{l}\stackrel{8}{0} \\
\text { i }\end{array}$ & 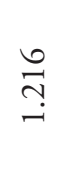 & $\hat{n}$ & $\begin{array}{l}\text { †े } \\
\text { }\end{array}$ & $\underset{\nearrow}{-}$ & ঔৃ. & $\underset{-}{\stackrel{+}{\tau}}$ & $\stackrel{\Re}{\curvearrowright}$ & $\stackrel{\overbrace{}}{\underset{\sim}{\sim}}$ & $\begin{array}{l}\hat{\infty} \\
\curvearrowleft\end{array}$ \\
\hline
\end{tabular}

statement S20 (think first in Slovene then write in English) where the BUN2 group again stood out from the other groups. Similar to before, BVS groups relied on Slovene when wanting to write something in English, with the BVS3 and BVS1 groups again being in the lead.

Focusing on the student-to-student interaction in class which is not task related, we observed that all groups have a high tendency to use Slovene when either asking their classmates for an explanation or explaining something to their classmates - all groups had average scores well above than 3.5. On the 5-point Likert scale, this means that overall they tend to do so frequently. This shows that students, including those who prefer 'English only' classes, do not consider communication with their classmates which is not task related as part of English language 
learning and an opportunity to maximize their use of English in class (despite the fact that they require 'English only' communication from the teacher). However, the reason for this behaviour might also be that they consider it odd to discuss some matters with their colleagues in English while they share the same first language.

Although many students would opt for 'English only' classes, S23 revealed that they would not insist on using English (or would not continue to use English) when they start talking to them in Slovene (the average score for S23 was between 1.42 and 2).

Looking at the correlations between these statements, we found that those students who would rather use Slovene during pair-work and group-work would also tend to use Slovene either to explain a point in the lesson to their classmates $(S 13+S 21: r=.383, p<.001)$ or ask their classmates for an explanation ( $\$ 13+\mathrm{S} 22$ : $\mathrm{r}=.317, \mathrm{p}<.001)$; also, we established that those students who would rather use Slovene than English in group activities believed that the use of Slovene makes group-work more efficient $(S 13+S 14: \mathrm{r}=.659, \mathrm{p}<.01)$. The same students would also tend to think in Slovene first about what they have to say in English.

Regarding those students who would think in Slovene first about what they have to say or write in English, we found that they would tend to disagree with the statement that the BE teacher should insist on the students' use of only English during lessons (should make them use English only). Indeed, they would prefer the teacher to allow the students to use Slovene if they felt like they could not express themselves adequately in English. These results indicate that the students who rely on Slovene for communication either with their classmates and/or teacher would not like the classes to be delivered entirely in English, or that the teacher should not insist on them using English only in class.

As with the previous two research questions, our study established a division into two groups of students. The 'English-only' group included those students who do not tend to use Slovene in group-work (pair-work) activities and also do not use Slovene in their preparation for speaking/ writing tasks. On the other hand, the students who do welcome the use of Slovene during Business English classes tend to use Slovene in group-work (pair-work) activities and tend to use Slovene in their preparation for speaking/writing. They also see the use of Slovene as a contributing factor to their efficiency in task completion. The level of Business English knowledge again played an important role in the students' responses.

\section{Conclusion}

Our study investigated business students' attitudes towards the use of Slovene in Business English courses. The most obvious finding to emerge from this study is that our students can be divided into two distinct groups as regards their attitude towards the use of Slovene when learning Business English. On the one hand, we have a strong group of students who would prefer 'English only' classes, since they see this approach as beneficial and motivating for their acquisition of Business English. These are also the students who, on average, perceive their knowledge of English either as very good or excellent. On the other hand, there are the students who rely on Slovene in their learning of Business English, usually because their English language knowledge is relatively poor and the possibility of using Slovene makes them feel less anxious.

Another important conclusion which can be drawn from our study is that in all six groups there were students who would prefer 'English only' classes and students who would like to use 
Slovene, too. In other words, what is perceived as useful and motivating for the study of Business English by some students is considered as demotivating by others.

The findings of this study therefore have some significant implications for teaching practice. The true challenge for the teacher is to find a balance between these opposing attitudes, since, in our opinion, they are both valid and have to be taken into account to attain the ultimate goal of teaching and learning, i.e., that our students become competent and confident users of English. The teacher could address these differences in students' opinions regarding the L1 use in class by explaining to students who prefer 'English only' classes why Slovene could or should be used in class (for instance, to raise awareness of the differences between the two languages, to present specialized terminology English and the equivalent terms in Slovene). On the other hand, those students who rely on the use of Slovene (mainly due to their lower level of English language proficiency) should learn that the more they use English and the less they rely on Slovene (even though the use of English might make them feel uncomfortable), the faster they will improve their English language proficiency. The latter could be achieved by arranging classroom work in mixed-ability groups, building on students' motivation and confidence through language tasks that are challenging, yet not too difficult to complete.

In conclusion, we should state that there is no 'one-size-fits-all' recipe for the use of L1 in class, as each teaching situation is different and requires the teacher to make a judicious decision regarding the use of L1. Future research on the use of L1 in the context of ESP teaching and learning which would focus on the individual aspects of teachers' and students' L1 use in various ESP contexts is thus welcome.

\section{References}

Al Sharaeai, Wafa Abdo Ahmed. 2012. "Students' Perspectives on the Use of L1 in English Classrooms.” Master's thesis, Iowa State University. http://lib.dr.iastate.edu/cgi/viewcontent. cgi?article $=3905 \&$ context $=$ etd.

Brooks-Lewis, Kimberly Anne. 2009. "Adult Learners' Perceptions of the Incorporation of Their L1 in Foreign Language Teaching and Learning." Applied Linguistics 30 (2): 216-35. doi:10.1093/applin/amn051.

Burden, Peter. 2000. “The Use of the Students' Mother Tongue in Monolingual English 'Conversation' Classes at Japanese Universities.” The Language Teacher Online 24 (6). http://jalt-publications.org/old_tlt/ articles/2000/06/burden.

Calis, Eda, and Kenan Dikilitas. 2012. "The Use of Translation in EFL Classes as L2 Learning Practice.” Procedia-Social and Behavioral Sciences 46: 5079-84. doi:10.1016/j.sbspro.2012.06.389.

Carrió-Pastor, María Luisa, and Inmaculada Tamarit Vallés. 2015. "A Comparative Study of the Influence of the Mother Tongue in LSP and CLIL.” Procedia-Social and Behavioral Sciences 178: 38-42. doi:10.1016/j. sbspro.2015.03.143.

Cianflone, Eugenio. 2009. "L1 Use in English Courses at University Level." ESP World 8 (22): 1-6. http://www.esp-world.info/Articles_22/PDF/L1\%20use\%20in\%20English\%20Courses\%20at\%20 University\%20Level.pdf .

Cook, Vivian. 2001a. Second Language Learning and Language Teaching. London, New York: Oxford University Press.

—. 2001b. "Using the First Language in the Classroom." Canadian Modern Language Review 57 (3): 402-23. doi: $10.3138 / \mathrm{cmlr}$.57.3.402. 
Debreli, Emre and Nadire Oyman. 2015. "Students' Preferences on the Use of Mother Tongue in English as a Foreign Language Classrooms: Is It the Time to Re-examine English-only Policies?” English Language Teaching 9 (1): 148-62. doi:10.5539/elt.v9n1p148.

Deller, Sheelagh, and Mario Rinvolucri. 2002. Using the Mother Tongue: Making the Most of the Learner's Language. London: English Teaching Professional; Addlestone: Delta.

Dujmović, Mauro. 2007. “The Use of Croatian in the EFL Classroom.” Metodički obzori 2 (3): 91-101.

Fakharzadeh, Mehrnoosh, and Abbass Eslami Rasekh. 2009. "Why's of Pro-First Language Use Arguments in ESP Context." English for Specific Purposes World 8 (5): 1-10.

Grosman, Meta. 2001. "Zavest o materinščini pri pouku tujih jezikov.” In Materni jezik na pragu 21. stoletja= The mother tongue on the doorstep of 21st century: Zbornik Mednarodnega simpozija Materni jezik na pragu 21. stoletja, Portorož, 2. december 1999. 32-39. Ljubljana: Zavod Republike Slovenije za šolstvo.

—. 2008. "Slovenščina in tuji jeziki - s stališča učenca." In Jeziki v izobraževanju: zbornik prispevkov konference, Ljubljana, 25.-26. septembra 2008 = Languages in education: proceedings, Ljubljana, September 25-26, 2008, 165-74. Ljubljana: Zavod RS za šolstvo.

Holc, Nada. 2010. "Večjezičnost kot dejstvo, cilj, obogatitev." In Drugi tuji jezik v osnovni šoli, edited by Lilijana Kač et al., 38-73. Ljubljana: Zavod RS za šolstvo.

Kavaliauskiene, Galina. 2009. "Role of Mother Tongue in Learning English for Specific Purposes." ESP World 8 (1): 1-12. http://www.esp-world.info/Articles_22/issue_22.htm.

Kovačić, Andreja and Valentina Kirinić. 2011. "To Use or Not to Use: First Language in Tertiary Instruction of English as a Foreign Language." In 1st International Conference on Foreign Language Teaching and Applied Linguistics, Sarajevo, May 5-7 2011, 150-59. http://eprints.ibu.edu.ba/26/1/FLTAL\%20 2011\%20Proceed\%C4\%B1ngs\%20Book_1_p150-p159.pdf.

Krashen, Stephen. 1981. Second Language Acquisition and Second Language Learning. Oxford: Pergamon.

Larsen-Freeman, Diane. 2000. Techniques and Principles in Language Teaching. 2nd ed. Oxford University Press.

Latsanyphone, Soulignavong, and Souvannasy Bouangeune. 2009. "Using L1 in Teaching Vocabulary to Low English Proficiency Level Students: A Case Study at the University of Laos.” English Language Teaching Journal 2 (3): 186-93. doi:10.5539/elt.v2n3p186.

Liao, Posen. 2006. "EFL Learners' Beliefs about and Strategy Use of Translation in English Learning." RELC Journal 37 (2): 191-215. doi:10.1177/0033688206067428.

Mutlu, Gizem, Dilan Bayram, and Buket Demirbüken. 2015. "Translation as a Learning Strategy of Turkish EFL Learners." International Journal on New Trends in Education \& Their Implications (IJONTE) 6 (2): 236-45.

Nation, Paul. "The Role of the First Language in Foreign Language Learning." Asian EFL Journal 5(2): 1-8. http://asian-efl-journal.com/june_2003_pn.pdf.

Nunan, David. 2004. Task-Based Language Teaching. Cambridge: Cambridge University Press.

Ostovar-Namaghi, Seyyed Ali and Shabnam Norouzi. 2015. "First Language Use in Teaching a Foreign Language: Theoretical Perspectives and Empirical Findings.” US-China Foreign Language 13: 615-22.

Pižorn, Karmen. 2008. "Vpliv domačih govorcev angleščine na rabo slovenščine pri pouku angleščine v slovenskih šolah.” In: Učenje in poučevanje tujih jezikov na Slovenskem: pregled sodobne teorije in prakse, edited by Janez Skela, 215-25. Ljubljana: Tangram.

Plos, Alenka, and Nada Puklavec. 2015. "Učiteljeva raba materinščine pri pouku tujega jezika stroke - da ali ne?” In: Raziskovanje tujega jezika stroke v Sloveniji, edited by Violeta Jurković and Slavica Čepon, 53-83. Ljubljana: Slovensko društvo učiteljev tujega strokovnega jezika. http://www.sdutsj.edus.si/ RaziskovanjeTJSvSloveniji. 
Sešek, Urška. 2009. "Naša učiteljica pa ves čas govori angleško!: pomen učiteljeve rabe jezika pri tujejezikovnem pouku." Vestnik za tuje jezike, 1 (1/2): 113-19.

Skela, Janez. 1994. "Materinščina pri poučevanju in učenju tujega jezika: zmota, potreba ali pravica?” Uporabno jezikoslovje 3: 72-83.

—. 2010. “Tuji jeziki in materinščina: vljudni gostje v našem domu ali vsiljivci?” In Pot k jezikovni politiki v izobraževanju, edited by Joseph Lo Bianco, Barica Marentič-Požarnik and Milena Ivšek, 136-64. Ljubljana: Zavod Republike Slovenije za šolstvo.

Stare Pušavec, Tanja. 2013. “Uporaba materinščine pri pouku tujega jezika.” In Turizem, izobraževanje in management: soustvarjanje uspešne poslovne prihodnosti: 4. znanstvena konferenca z mednarodno udeležbo, 24.-25. oktober 2013, Portorož: zbornik povzetkov = proceedings, 263-64. Koper: Založba Univerze na Primorskem.

Tang, Jinlan. 2002. "Using L1 in the English Classroom.” English Teaching Forum 40 (1): 36-43.

Taylor, Pimsiri. 2014. "Mother Tongue and Identity in a Thai ESP Classroom: A Communities-of-Practice Perspective." LEARN Journal: Language Education and Acquisition Research Network 7 (1): 76-90.

Topolska-Pado, Jadwiga. 2011. "Use of L1 and Tin the EFL Classroom." Zeszyty Glottodydaktyczne 3: 11-25.

Widdowson, Henry. 2003. Defining Issues in English Language Teaching. Oxford: Oxford University Press.

Xhemaili, Mirvan. 2016. "The Advantages and Disadvantages of Mother Tongue in Teaching and Learning English for Specific Purposes (ESP) Classes." ANGLISTICUM. Journal of the Association for AngloAmerican Studies 2 (3): 191-95. 